\title{
Oxygen Tension Regulates the Nitric Oxide Pathway Physiological Role in Penile Erection
}

\author{
Noel Kim, Yoram Vardi, * Harin Padma-Nathan, ${ }^{\star}$ Jennifer Daley, Irwin Goldstein, and Iñigo Saenz de Tejada \\ Departments of Urology, Boston University School of Medicine, Boston, Massachusetts 02118; *Rambam Medical Center, \\ Haifa, 31096 Israel; and ${ }^{\ddagger}$ University of Southern California School of Medicine, Los Angeles, California 90033
}

\begin{abstract}
Relaxation of the trabecular smooth muscle of the corpus cavernosum (the erectile tissue) of the penis is mediated by nitric oxide released by the nerves and endothelium. We have investigated the physiological role of oxygen tension in the regulation of trabecular smooth muscle tone. In human subjects, measurement of intracavernosal $\mathrm{Po}_{2}$ in blood drawn from corpus cavernosum in the flaccid state was comparable to that of venous blood ( $25-43 \mathrm{mmHg}$ ). Vasodilatation of the resistance arteries and trabecular smooth muscle relaxation by intracavernosal injection of papaverine and phentolamine caused oxygen tension to rise rapidly to arterial levels $\left(\mathrm{PO}_{2} \sim 100 \mathrm{mmHg}\right)$. Isolated human and rabbit corpus cavernosum tissue strips in organ baths, exposed to arterial-like $\mathrm{Po}_{2}$ relaxed to the endothelium-dependent dilator acetylcholine and to electrical stimulation of the autonomic dilator nerves. These nitric oxidemediated responses were progressively inhibited as a function of decreasing $\mathrm{PO}_{2}$ to levels measured in the flaccid penis. Reverting to normoxic conditions readily restored endotheliumdependent and neurogenic relaxation. Relaxation to exogenous nitric oxide was not impaired in low $\mathrm{Po}_{2}$. In rabbit corpus cavernosum, low $\mathrm{PO}_{2}$ reduced basal levels of cGMP and prevented cGMP accumulation induced by stimulation of dilator nerves. Furthermore, low $\mathrm{PO}_{2}$ inhibited nitric oxide synthase activity in corpus cavernosum cytosol. It is concluded that physiological concentrations of oxygen modulate penile erection by regulating nitric oxide synthesis in corpus cavernosum tissue. ( $J$. Clin. Invest. 1993. 91:437-442.) Key words: hypoxia • nitric oxide synthase $\bullet$ corpus cavernosum • endothelium-dependent relaxation • neurogenic relaxation
\end{abstract}

\section{Introduction}

During erection, the penis acts as a capacitor, accumulating blood under pressure (1). This function depends on two key events: (a) dilation of the resistance arterial bed of the penis, enhancing blood flow and pressure to the corpora cavernosa; and $(b)$ relaxation of the trabecular smooth muscle, allowing the expansion of the lacunar spaces and trapping of blood by compression of the peripheral draining venules (veno-occlusive mechanism) (2). Trabecular smooth muscle relaxation is

Address correspondence to Iñigo Saenz de Tejada, M.D., 720 Harrison Avenue, P606, Department of Urology, Boston University Medical Center, Boston, MA 02118.

Received for publication 17 December 1991 and in revised form 14 September 1992.

J. Clin. Invest.

(C) The American Society for Clinical Investigation, Inc.

0021-9738/93/02/0437/06 \$2.00

Volume 91, February 1993, 437-442 associated with a rise in intracellular cGMP levels and is mediated by nitric oxide (NO) ${ }^{1}$ released from the endothelium and the autonomic dilator nerves innervating the trabeculae (3-7). The synthesis of nitric oxide is mediated by NO synthase which, in addition to L-arginine, requires oxygen as a substrate (8-10). Furchgott and Zawadsky initially reported in blood vessels that responses to endothelium-derived relaxing factor, later shown to be nitric oxide (11), were inhibited at low oxygen tensions (12), an observation corroborated by other investigators $(3,13-16)$. However, the physiological significance of this observation remains unclear.

To determine the possible regulatory role of oxygen tension in penile erection, we have measured intracavernosal blood oxygen tension, in vivo, in the flaccid and erect states of the penis in humans. Biopsies of human and rabbit corpus cavernosum were then studied in vitro to determine the effect of physiological oxygen tensions on nitric oxide-mediated relaxation. The effects of hypoxia were also correlated with changes in cGMP levels and NO synthase activity in corpus cavernosum.

\section{Methods}

\section{Materials}

Bretylium tosylate (2-bromo- $N$-ethyl- $N, N$-dimethylbenzenemethanaminium 4-methylbenzenesulfonate) was obtained from American Critical Care (McGraw Park, IL). Zaprinast (M\&B 22948) was a gift from Rhône-Poulenc Ltd. (Dagenham Essex, England). L- $\left[2,3-{ }^{3} \mathrm{H}\right]$ arginine ( $58.4 \mathrm{Ci} / \mathrm{mmol}$ ) was purchased from Du Pont Co./New England Nuclear Research Products ( Boston, MA). Liquiscint was purchased from National Diagnostics (Manville, NJ). Solutions of norepinephrine (4(2-amino-1-hydroxyethyl)-1,2-benzenediol) contained $0.1 \%$ ascorbate (wt/vol) as an antioxidant. All gas mixtures were obtained through Medical-Technical Gases, Inc. (Medford, MA) and Welders Supply Co./Cryogenics-East, Inc. (Billerica, MA). All other drugs and reagents were purchased from commercially available sources.

\section{Buffers}

Physiological salt solution (PSS). $118.3 \mathrm{mM} \mathrm{NaCl} ; 25.0 \mathrm{mM}$ $\mathrm{NaHCO}_{3} ; 11.1 \mathrm{mM}$ D-glucose; $4.7 \mathrm{mM} \mathrm{KCl} ; 2.5 \mathrm{mM} \mathrm{CaCl}_{2} ; 1.2 \mathrm{mM}$ $\mathrm{KH}_{2} \mathrm{PO}_{4} ; 0.6 \mathrm{mM} \mathrm{MgSO}_{4} ; 0.026 \mathrm{mM} \mathrm{CaNa}_{2}$ EDTA.

HSE. $20 \mathrm{mM}$ Hepes, pH 7.2; $320 \mathrm{mM}$ sucrose; $0.5 \mathrm{mM} \mathrm{Na}_{2}$ EDTA; $1 \mathrm{mM}$ DTT.

HE. 5 mM Hepes, pH 5.5; 2 mM Na${ }_{2}$ EDTA.

In vivo studies

A group of 10 patients was subjected to a complete erectile function evaluation that included hormonal profile, neurological tests, cavernosal infusion of vasorelaxants, and nocturnal penile tumescence monitoring with simultaneous recording of electroencephalographic and electrooculographic activity. All patients participating in the study

1. Abbreviations used in this paper: L-NOARG, $N^{\omega}$-nitro-L-arginine; NO, nitric oxide; PSS, physiological salt solution. 
were evaluated to have normal erectile function tests. Six patients had some degree of penile curvature. All patients issued informed consent and experimental protocols were approved by the local Institutional Review Boards for Human Studies. Using a pressure transducer and a recorder, intracavernosal pressure was monitored through a 19-gauge needle inserted directly into one of the cavernosal bodies. This same needle was also used to draw blood for $\mathrm{PO}_{2}$ measurements. Infusion of drugs was achieved through a second 19-gauge needle inserted into the contralateral cavernosal body. After basal blood pressure and gas values were determined, patients were injected with $60 \mathrm{mg}$ papaverine and $2 \mathrm{mg}$ phentolamine. Blood samples were drawn at the indicated times and $\mathrm{PO}_{2}$ values were immediately measured with an acid-base analyzer (Model ABL 30; Radiometer Copenhagen, Copenhagen, Denmark).

\section{Tissue procurement}

Human. Human corporal biopsies were obtained from eight impotent men at the time of penile prosthesis implantation as previously described (3). Human corpus cavernosum tissue was also obtained from three patients with a history of normal penile erections undergoing radical prostatectomy. Because the prostatectomy was done with a non-nerve sparing technique that results in neurogenic and/or vasculogenic impotence, these patients opted for a two-stage implantation of a penile prosthesis. Corporal biopsies were obtained at the first stage (at the time of prostatectomy) before nerve and/or vascular damage. Since the purpose of this study was not to compare the responsiveness of tissues between potent and impotent men, and no significant qualitative differences were observed in the reactivity of cavernosal tissue between the two groups, the data were grouped for this study. Protocols for the procurement of corporal biopsies were approved by the local Institutional Review Board for Human Studies. All tissue donors issued informed consent. Tissues were transported to the laboratory in ice-cold PSS for immediate study. Strips of human corpus cavernosum $(3 \times 3 \times 7 \mathrm{~mm})$ were cut from the corporal biopsy and mounted in organ baths (see below).

Rabbit. Penile corpus cavernosum tissue strips were obtained from male New Zealand White rabbits $(3.0-3.5 \mathrm{~kg}$ ) as previously described (3). The protocol was approved by the Animal Care Committee at the Boston University Medical Center.

\section{Organ bath studies of isolated tissue strips}

Strips of human or rabbit corpus cavernosum were mounted to tension transducers and submerged in thermostated $\left(37^{\circ} \mathrm{C}\right) 25 \mathrm{ml}$ organ baths containing bicarbonate buffered PSS and aerated with $95 \%$ air $/ 5 \% \mathrm{CO}_{2}$ (normoxic conditions) to attain pH 7.4. Optimal isometric tension for contraction was attained as described previously (3). Tissues were treated with $1 \mu \mathrm{M}$ indomethacin (a cyclooxygenase inhibitor) and 10 $\mu \mathrm{M}$ bretylium (an inhibitor of adrenergic neurotransmission) throughout the experiment.

Responses to acetylcholine and electrical stimulation. Tissue strips were contracted with $0.1 \mu \mathrm{M}$ norepinephrine (4-(2-amino-1-hydroxyethyl)-1,2-benzenediol) and subjected to either increasing concentrations of acetylcholine (2-(acetyloxy)- $N, N, N$-trimethylethanaminium chloride) by cumulative addition or electrical stimulation at the indicated frequencies, as previously described (3). After several exchanges of fresh PSS, the bathing media were bubbled with gas mixtures containing the indicated concentrations of oxygen, $5 \% \mathrm{CO}_{2}$, and balance $\mathrm{N}_{2}$ for $30 \mathrm{~min}$. The $\mathrm{Po}_{2}$ values (mean $\pm \mathrm{SD}$ ) for the various gas mixtures were as follows: $95 \%$ air $($ normoxia $)=147 \pm 5 \mathrm{mmHg} ; 6 \% \mathrm{O}_{2}=49 \pm 4$ $\mathrm{mmHg} ; 4 \% \mathrm{O}_{2}=32 \pm 3 \mathrm{mmHg} ; 3 \% \mathrm{O}_{2}=27 \pm 3 \mathrm{mmHg}$. The tissues were contracted again with norepinephrine, and the electrical stimulations and the acetylcholine dose responses were repeated. In some of the experiments, after a second wash period, the gassing mixture was changed back to normoxic conditions and the protocol was repeated a third time.

Nitric oxide dose response. As described previously (3), nitric oxide gas was bubbled through deoxygenated water in test tubes for $10 \mathrm{~min}$ to yield a saturated solution of aqueous nitric oxide $\left(\sim 10^{-3} \mathrm{M}\right)$. Serial dilutions were performed by transferring aliquots with a syringe between rubber-stoppered tubes containing deoxygenated water. Stock solutions were used within $15 \mathrm{~min}$ of preparation and discarded after each use.

\section{cGMP measurements}

Incubations. Rabbit corpus cavernosum tissue strips were tied with surgical suture to Teflon catheters and submerged in $25 \mathrm{ml}$ baths containing PSS, aerated $\left(\mathrm{PO}_{2}=147 \pm 5 \mathrm{mmHg}\right)$, and thermostated at $37^{\circ} \mathrm{C}$. Tissues were washed and equilibrated in PSS for $1 \mathrm{hr}$ and were not stretched or subjected to active tension. Indomethacin $(3 \mu \mathrm{M})$, bretylium $(10 \mu \mathrm{M})$, and atropine $(0.1 \mu \mathrm{M})$ were then added to the baths and the tissue strips were incubated for $30 \mathrm{~min}$. After washing with fresh PSS, tissues were subjected to a second 30-min incubation in the presence of $100 \mu \mathrm{M}$ zaprinast, as well as indomethacin, bretylium, and atropine. Also during this incubation period, some tissues were treated with $50 \mu \mathrm{M} N^{\omega}$-nitro-L-arginine (L-NOARG) or aerated with $1 \% \mathrm{O}_{2}, 5 \% \mathrm{CO}_{2}, 94 \% \mathrm{~N}_{2}$ gas mixture. All tissue strips were then exposed to $1 \mu \mathrm{M}$ phenylephrine for $20 \mathrm{~min}$. Tissues were subjected to electrical stimulation with a train of square waves for $20 \mathrm{~s}$ at $5 \mathrm{~Hz}, 10 \mathrm{~V}$, and $0.5 \mathrm{~ms}$ pulse duration. After stimulation, the tissue strips were removed from the baths and rapidly frozen by submerging them in liquid nitrogen. Frozen tissues were pulverized into powder and stored at $-80^{\circ} \mathrm{C}$.

Tissue extraction and cGMP assay. Tissue powders were homogenized in $1 \mathrm{ml}$ of $1 n$ perchloric acid using a glass-glass tissue grinder. Crude homogenates were transferred to clean test tubes and combined with an $0.5-\mathrm{ml}$ water rinse of the homogenizing vessel. Samples were centrifuged at $3,000 \mathrm{~g}$ for $30 \mathrm{~min}$. at $2^{\circ} \mathrm{C}$. The pellets were saved for protein assay and the resulting supernatants were transferred to clean test tubes and neutralized with $0.6 \mathrm{ml}$ of $2 n \mathrm{KOH} / 0.5 \mathrm{M}$ triethanolamine. The precipitate was removed by centrifugation. To the supernatant, $750 \mu \mathrm{l}$ of water and $150 \mu \mathrm{l}$ of $1 \mathrm{M}$ sodium acetate ( $\mathrm{pH} 5.8$ ) were added to yield a final concentration of $50 \mathrm{mM}$ acetate. An aliquot of each sample was further diluted (fivefold) with $50 \mathrm{mM}$ acetate $(\mathrm{pH}$ 5.8) and acetylated cGMP was quantitated using a commercially available radioimmunoassay kit (Amersham Corp., Arlington Heights, IL). Pellet samples saved for protein assay were solubilized in $0.5 \mathrm{ml}$ of $1 \mathrm{n}$ $\mathrm{NaOH}$ by heating at $80-90^{\circ} \mathrm{C}$ for $10-15 \mathrm{~min}$. Nonsoluble material was removed by centrifugation and supernatants were diluted 10 -fold to reduce the concentration of $\mathrm{NaOH}$ to $0.1 n$. Aliquots of the diluted supernatants were then assayed for protein by the method of Lowry et al. (17).

\section{Measurement of nitric oxide synthase activity}

To assess the activity of NO synthase, the procedures described by Bredt and Snyder (18) and Rengasamy and Johns (19) for the cerebellum were adapted for use in corpus cavernosum tissue.

Cytosol preparation. Rabbit corpus cavernosum tissue was frozen and pulverized into powder, using a ground glass pestle homogenizer. The tissue powder, pooled from several animals, was homogenized on ice with HSE buffer ( $4 \mathrm{ml} / \mathrm{g}$ tissue powder) in the presence of $0.5 \mathrm{mM}$ PMSF, $1 \mu \mathrm{M}$ pepstatin $\mathrm{A}$, and $2 \mu \mathrm{M}$ leupeptin. The homogenate was transferred to ultracentrifuge tubes and centrifuged at $20,000 \mathrm{~g}$ for $45 \mathrm{~min}$ at $2^{\circ} \mathrm{C}$. The resulting supernatant (cytosol) was kept on ice until use.

Purification of $\left[{ }^{3} \mathrm{H}\right]$ arginine. Purification of $\left[{ }^{3} \mathrm{H}\right]$ arginine for the purpose of removing products of arginine decomposition, such as $\left[{ }^{3} \mathrm{H}\right]-$ citrulline, was achieved by passing $200 \mu \mathrm{Ci}$ of $\left[{ }^{3} \mathrm{H}\right]$ arginine (in deionized water, $2 \%$ ethanol) through a $2-\mathrm{ml}$ column of AG1-X8 resin (hydroxide form, 100-200 mesh; Bio-Rad Laboratories, Richmond, CA) an anion exchanger. The column was washed with $5 \mathrm{ml}$ of deionized water and all effluent was collected. The purified $\left[{ }^{3} \mathrm{H}\right]$ arginine was then frozen in small aliquots. This procedure greatly reduced background counts in the NO synthase assay.

Incubations. An aliquot of the cytosol was set aside for protein determination. Each incubation mixture ( $200 \mu l$ total) contained 150 
$\mu$ l of cytosol, $2 \mathrm{mM} \mathrm{NADPH}, 0.45 \mathrm{mM} \mathrm{CaCl}_{2}, 100 \mu \mathrm{M}$ L-arginine, and $5 \mu \mathrm{Ci} \mathrm{L}-\left[2,3-{ }^{3} \mathrm{H}\right]$ arginine $/ \mathrm{ml}$ of incubation. Time-dependent $\left[{ }^{3} \mathrm{H}\right]-$ citrulline synthesis was determined by incubating samples (in duplicate) in a water bath at $37^{\circ} \mathrm{C}$ for $0,5,10,15,30,45$, and $60 \mathrm{~min}$. A parallel set of incubations was performed at $2^{\circ} \mathrm{C}$, and a third set containing $3 \times 10^{-5} \mathrm{M} \mathrm{L}-\mathrm{NOARG}$ was performed at $37^{\circ} \mathrm{C}$. Incubations were terminated by the addition of $2 \mathrm{ml}$ of ice-cold HE buffer. Samples were passed through a 1-ml column of AG $50 \mathrm{~W}-\mathrm{X} 8\left(\mathrm{Na}^{+}\right.$form, $100-$ 200 mesh; Bio-Rad Laboratories) and eluted with $2 \mathrm{ml}$ of $\mathrm{HE}$ buffer. The positively charged $\left[{ }^{3} \mathrm{H}\right]$ arginine is retained by the column, whereas the $\left[{ }^{3} \mathrm{H}\right]$ citrulline passes through unhindered. Eluates were collected in vials, mixed with Liquiscint and counted in a Packard Tri-Carb 460CD refrigerated liquid scintillation counter.

For hypoxic incubations, the cytosol and stocks were degassed on ice for $30 \mathrm{~min}$, then combined, exposed to a nitrogen environment, and placed in a $37^{\circ} \mathrm{C}$ water bath for $15 \mathrm{~min} . \mathrm{N}_{2}$ gas was passed over the reaction mixture during the incubation period through a needle inserted into a rubber-stoppered vial. A second needle was inserted into the rubber cap to act as a vent. Cytosol treated in this manner yielded a $\mathrm{PO}_{2}$ value ranging from 15 to $25 \mathrm{mmHg}$, as determined by measurement with an oxygen needle electrode (Diamond General Corp., Ann Arbor, MI). Incubations were also performed at $37^{\circ} \mathrm{C}$ for $15 \mathrm{~min}$ under normoxic conditions $\left(\mathrm{PO}_{2}\right.$ in the $130-145$ range). A parallel set of incubations were carried out at $2^{\circ} \mathrm{C}$ for 15 min under both normoxic and hypoxic conditions and were considered as background or nonspecific activity. Incubations were terminated and processed in the same manner as the time course samples. The specific activity of the $\left[{ }^{3} \mathrm{H}\right]-$ arginine was corrected for endogenous $\mathrm{L}$-arginine content, as determined by HPLC analysis of cytosolic extract from corpus cavernosum after TCA $(10 \%)$ precipitation. It was determined that $1 \mathrm{~g}$ of corpus cavernosum tissue yielded $134.7 \pm 7.6 \mathrm{nmol} \mathrm{L}$-arginine. Nonspecific activity, as determined by parallel incubations performed at $2^{\circ} \mathrm{C}$, was subtracted from each corresponding incubation performed at $37^{\circ} \mathrm{C}$ before citrulline production was calculated.

Calculations for organ bath experiments. As previously described (3), all responses are expressed as percentage of maximal relaxation that was induced by the addition of $0.1 \mathrm{mM}$ papaverine (1-[(3,4-dimethoxy-phenyl)methyl]-6,7-dimethoxyisoquinoline hydrochloride) at the end of the experiment. Data are expressed as mean $\pm \mathrm{SE}$ for $n$ different individuals, unless stated otherwise. Statistical significance was determined by analysis of variance followed by paired comparisons with control (normoxic) responses using $t$ test.

\section{Results}

In vivo studies. In human subjects, blood gas and intracavernosal pressure values were monitored simultaneously. Erections were induced by intracavernosal injection of the vasodilator papaverine and the alpha adrenergic antagonist phentolamine. These drugs cause both arterial and trabecular smooth muscle to relax. In the flaccid state, the mean $\mathrm{Po}_{2}$ value was $34.1 \pm 7.4$ $\mathrm{mmHg}$ (range $=25-43 \mathrm{mmHg} ; n=10$ ). Upon stimulation by injection with papaverine and phentolamine, the mean $\mathrm{PO}_{2}$ value increased to $99 \pm 2.8 \mathrm{mmHg}$, reaching $85 \%$ of the peak value by $1 \mathrm{~min}$ (Fig. 1). Simultaneous measurement of intracavernosal pressure revealed a slower rate of increase with a lag phase within the first $60 \mathrm{~s}$.

Isometric tension measurements. To characterize this phenomenon further, we studied neurogenic and endothelium-dependent relaxation of the trabecular smooth muscle in vitro (organ baths). Human and rabbit corporal tissue strips were exposed to varying oxygen tensions within the physiological range measured in corpus cavernosum blood. In tissues contracted with norepinephrine and exposed to increasing concentrations of acetylcholine, relaxation was progressively atten- uated as a function of decreasing $\mathrm{PO}_{2}$ in the bathing medium in human and rabbit tissues (Figs. 2 and 3). However, in human tissue, no significant inhibition was observed at $6 \% \mathrm{O}_{2}\left(\mathrm{PO}_{2}\right.$ $=44-57 \mathrm{mmHg}$ ) (Fig. 2). Likewise, human and rabbit tissue strips that were contracted with norepinephrine and stimulated electrically relaxed poorly when subjected to oxygen tensions comparable to those measured in the flaccid state of the penis (Figs. 4 and 5). As with endothelium-mediated relaxation, inhibition of neurogenic relaxation of human cavernosal smooth muscle occurred at oxygen tensions below $\sim 50 \mathrm{mmHg}(6 \%$ $\mathrm{O}_{2}$ ) (Fig. 4). The inhibitory effect of hypoxia on endotheliummediated and neurogenic relaxation was readily reversed upon returning to normoxic conditions (Figs. 2-5). However, as can be seen from Fig. 6, relaxation of human and rabbit corpus cavernosum to exogenous nitric oxide was unaffected by either hypoxia $\left(3 \% \mathrm{O}_{2}\right)$ or anoxia $\left(0 \% \mathrm{O}_{2}\right)$.

Measurement of cyclic GMP accumulation. Since nitric oxide stimulates soluble guanylate cyclase, accumulation of cGMP may be correlated with nitric oxide production. The effects of hypoxia and the NO synthesis inhibitor L-NOARG on cGMP accumulation elicited by electrical stimulation of the autonomic dilator nerves were investigated. In rabbit corpus cavernosum tissues incubated with indomethacin, bretylium, and atropine, basal levels of cGMP were reduced in the presence of $50 \mu \mathrm{M}$ L-NOARG or under hypoxic conditions (Fig. 7). Transmural electrical stimulation in the presence of adrenergic and cholinergic blockade raised cGMP levels $78 \pm 18 \%$ in control tissues, whereas L-NOARG or low oxygen tensions either significantly reduced or prevented this increase in cGMP (Fig. 7).

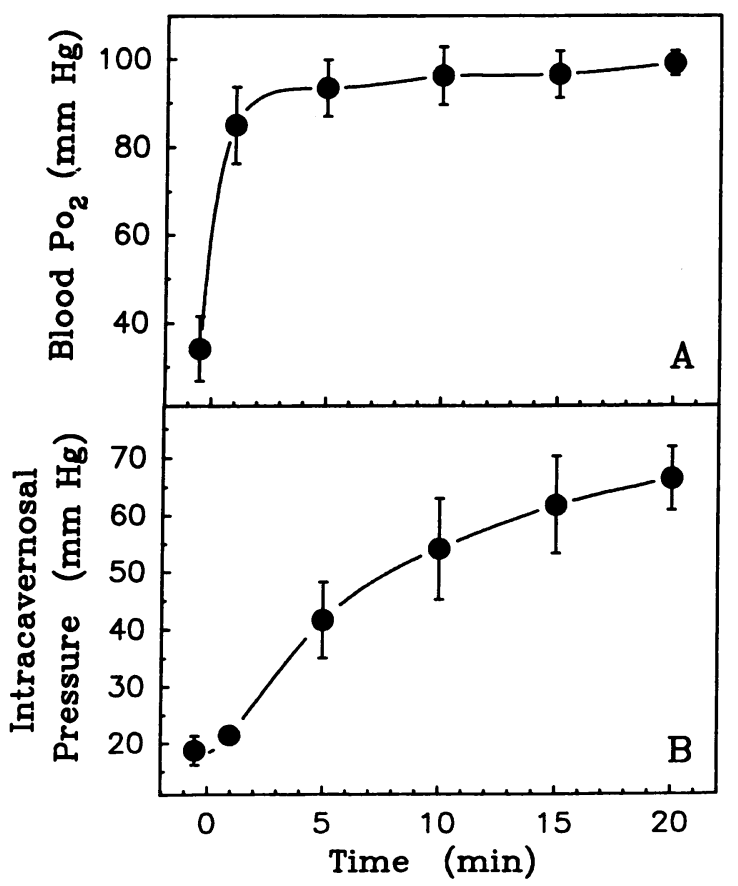

Figure 1. In vivo measurements of intracavernosal blood $\mathrm{Po}_{2}(A)$ and pressure $(B)$ in humans. Patients $(n=10)$ were injected with papaverine and phentolamine at time 0 and intracavernosal pressure was monitored. Blood samples were drawn at the indicated times, and $\mathrm{PO}_{2}$ values were immediately measured. Basal values were obtained just before drug injection. Values are expressed as mean \pm SD. 

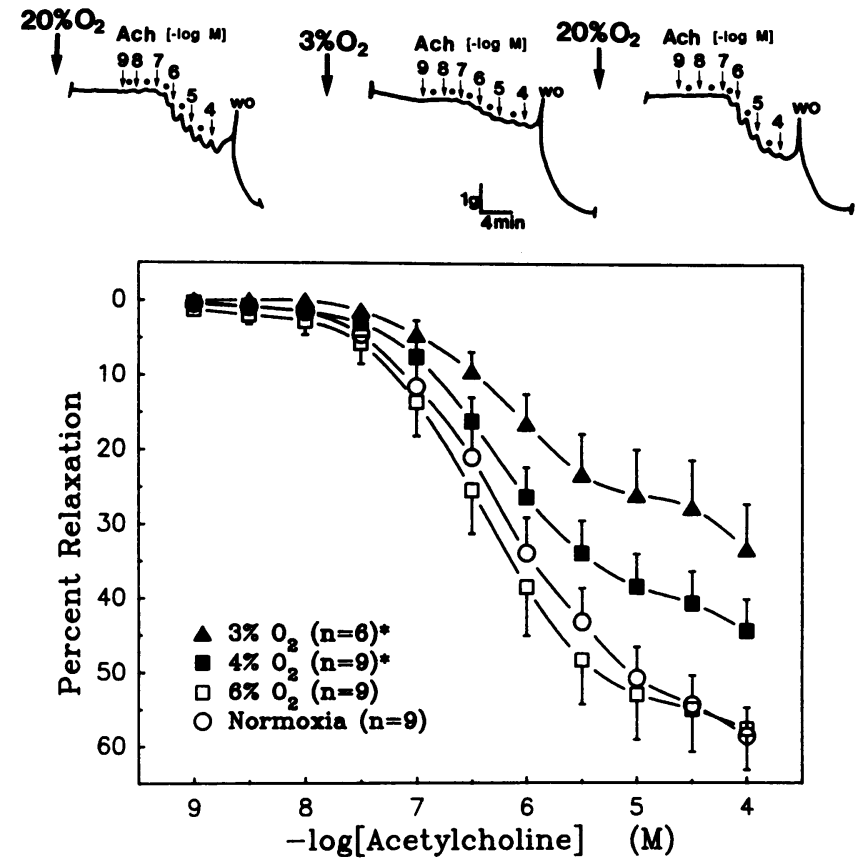

Figure 2. Effect of hypoxia on responses to exogenous acetylcholine in isolated strips of human corpus cavernosum. Under normoxic conditions, tissue strips submerged in organ baths were contracted with 0.1 $\mu \mathrm{M}$ norepinephrine and exposed to increasing concentrations of acetylcholine in a cumulative fashion. After a 30-min incubation under various states of hypoxia (see Methods for $\mathrm{PO}_{2}$ values), acetylcholine dose responses were repeated. The protocol was repeated a third time after reverting back to normoxic conditions (summarized data not shown). Isometric tension recordings are shown above the summarized data in graphical form. *Indicates statistically significant differences $(P \leq 0.01)$ in the extent of relaxation as assessed by analysis of variance followed by paired comparisons with control (normoxic) responses using $t$ test. All values are expressed as mean \pm SE.

Measurement of NO synthase activity. Nitric oxide synthase activity was assessed in the cytosolic fraction of rabbit corpus cavernosum tissue homogenates by measuring the production of $L-\left[{ }^{3} \mathrm{H}\right]$ citrulline from $\mathrm{L}-\left[{ }^{3} \mathrm{H}\right]$ arginine. In samples that were incubated at $37^{\circ} \mathrm{C},\left[{ }^{3} \mathrm{H}\right]$ citrulline production increased in a linear fashion over the time course assayed (0-60 $\min$ ). In contrast, samples incubated at $37^{\circ} \mathrm{C}$ in the presence of L-NOARG exhibited a minimal increase in $\left[{ }^{3} \mathrm{H}\right]$ citrulline formation comparable to incubations performed at $2^{\circ} \mathrm{C}$. In control incubations under normoxic conditions ( cytosol $\mathrm{PO}_{2} 130$ $150 \mathrm{mmHg}$ ) at $37^{\circ} \mathrm{C}$, rabbit NO synthase produced $0.38 \pm 0.02$ $\mathrm{nmol}$ citrulline/mg protein in a period of $15 \mathrm{~min}$ (Fig. 8). Incubations that were performed under nitrogen atmosphere (cytosol $\mathrm{PO}_{2} 15-25 \mathrm{mmHg}$ ) exhibited a significant reduction $(60 \%)$ in citrulline synthesis.

\section{Discussion}

Our data suggest that oxygen tension plays an active role in regulating penile erection in the following manner: Blood oxygen tensions in the corpus cavernosum are close to venous $\mathrm{PO}_{2}$ levels in the flaccid state. At these oxygen tensions, synthesis of nitric oxide in corpus cavernosum is inhibited, preventing trabecular smooth muscle relaxation. Sacral parasympathetic

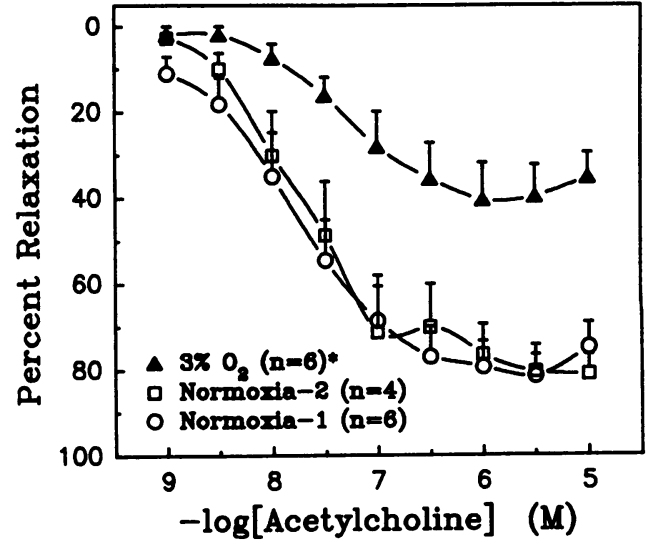

Figure 3. Effect of hypoxia on responses to exogenous acetylcholine in isolated strips of rabbit corpus cavernosum. Rabbit tissues were subjected to acetylcholine dose responses, as described in Fig. 2. Initial dose responses are designated as Normoxia-1 (95\% air), while responses obtained after reverting back to normoxic conditions $(95 \%$ air) after a hypoxic $\left(3 \% \mathrm{O}_{2}\right)$ episode are designated as Normoxia- 2 . ( ${ }^{*} P \leq 0.0005$, as determined by $t$ test comparing hypoxic vs. normoxic conditions.)

stimulation initiates vasodilatation of the resistance arterial bed and enhances intracavernosal blood oxygen content caused by increased flow. In this oxygen-enhanced environment, autonomic dilator nerves and the endothelium are able to synthesize nitric oxide, mediating trabecular smooth muscle relaxation that is necessary for the entrapment of blood in the corpora during penile erection.
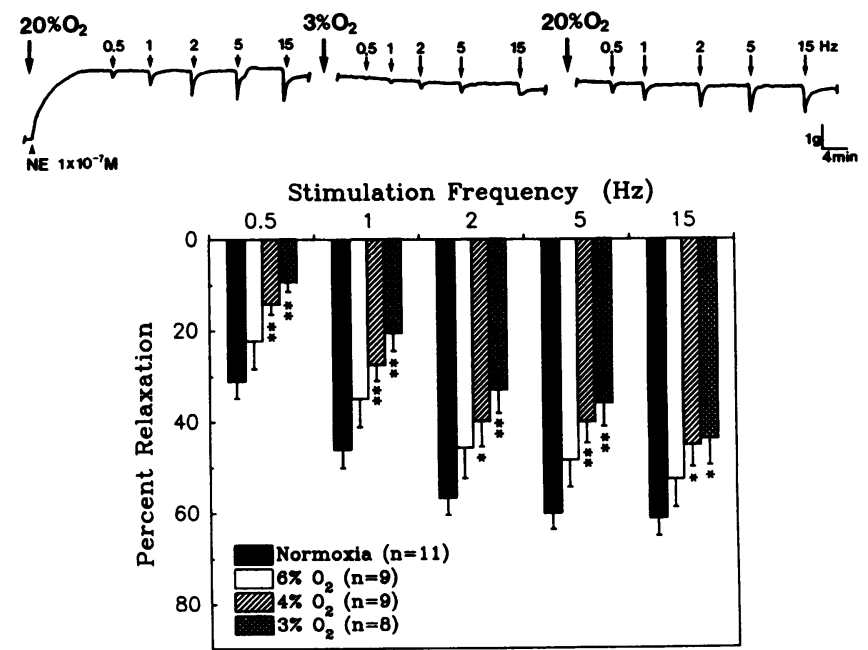

Figure 4. Effect of hypoxia on responses to electrical stimulation in human corpus cavernosum. Tissue strips submerged in organ baths were contracted with $0.1 \mu \mathrm{M}$ norepinephrine and electrically stimulated at the indicated frequencies under normoxic conditions in the presence of indomethacin and bretylium. After a 30-min incubation under various states of hypoxia (see Methods for $\mathrm{PO}_{2}$ values), electrical stimulations were repeated. The protocol was repeated a third time after reverting back to normoxic conditions (summarized data not shown). Isometric tension recordings are shown above the summarized data in graphical form. All values are expressed as mean $\pm \mathrm{SE}$. *Indicate statistically significant differences as assessed by analysis of variance followed by paired comparisons with control (normoxic) responses using $t$ test $\left({ }^{*} P \leq 0.01,{ }^{* *} P \leq 0.005\right)$. 


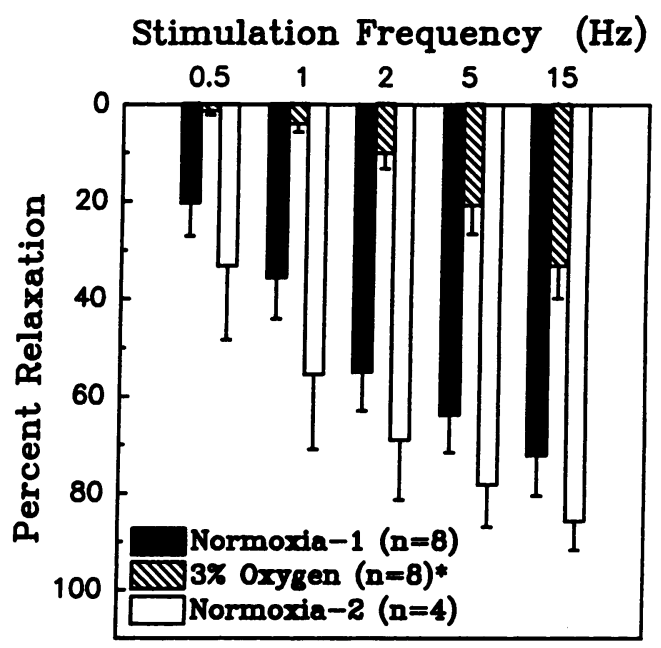

Figure 5. Effect of hypoxia on responses to electrical stimulation in rabbit corpus cavernosum. Rabbit tissues were subjected to electrical stimulation, as described in Fig. 4. Initial stimulations are designated as Normoxia-1 (95\% air), while responses obtained after reverting back to normoxic conditions ( $95 \%$ air) after a hypoxic $\left(3 \% \mathrm{O}_{2}\right)$ episode are designated as Normoxia-2. ( ${ }^{*} P \leq 0.01$ at all frequencies, as determined by $t$ test comparing hypoxic vs. normoxic conditions).

In previous work, we (3) and others (4-7) have shown that trabecular smooth muscle relaxation induced by both the nerves and the endothelium is mediated by nitric oxide or a similar substance. Low oxygen tensions may interfere with the synthesis or secretion of nitric oxide or alter its availability upon release. It is also possible that the target cell (the smooth muscle) is less responsive to NO under hypoxic conditions. As NO readily diffuses across cell membranes, there is no apparent oxygen requirement for NO release. Since low oxygen tensions did not inhibit relaxation of corpus cavernosum smooth muscle to authentic NO, this would suggest that NO can diffuse into the target cell, that it is not more actively metabolized in a low oxygen environment, and that the responsiveness of the

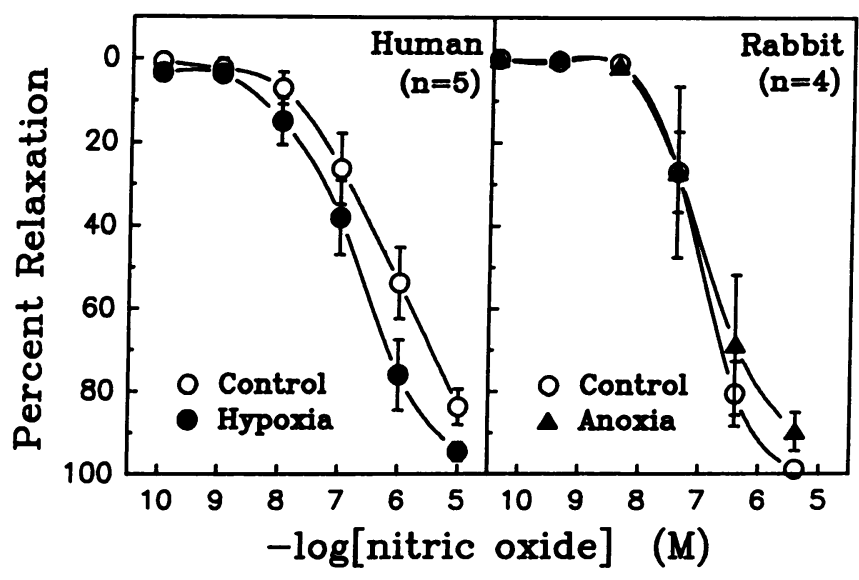

Figure 6. Effect of hypoxia on responses to exogenous nitric oxide in human and rabbit corpus cavernosum. Tissue strips submerged in organ baths were contracted with $0.1 \mu \mathrm{M}$ norepinephrine and exposed to increasing concentrations of aqueous nitric oxide. After several exchanges of fresh PSS, the bathing medium was bubbled with $3 \%$ $\mathrm{O}_{2}$ or $0 \% \mathrm{O}_{2}$ gas mixture for $30 \mathrm{~min}$. The tissues were contracted again with norepinephrine and the nitric oxide dose response was repeated. All values are expressed as mean \pm SE.

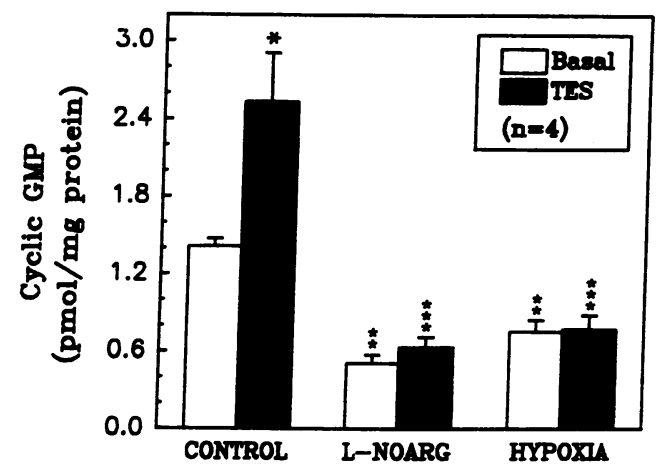

Figure 7. Cyclic GMP accumulation in rabbit corpus cavernosum. Strips of rabbit corpus cavernosum were incubated in aerated PSS (Control, $\mathrm{Po}_{2}=147 \pm 5 \mathrm{mmHg}$ ) at $37^{\circ} \mathrm{C}$ in the presence of $3 \mu \mathrm{M}$ indomethacin, $10 \mu \mathrm{M}$ bretylium, $0.1 \mu \mathrm{M}$ atropine, $100 \mu \mathrm{M}$ zaprinast (M\&B 22948), and $1 \mu M$ phenylephrine. Some tissues were also incubated with $50 \mu \mathrm{M}$ L-NOARG or under hypoxic conditions. All tissue strips were then electrically stimulated at $5 \mathrm{~Hz}$ for $20 \mathrm{~s}$ and rapidly frozen by submerging them in liquid nitrogen. Tissues were homogenized in perchloric acid and assayed for CGMP by radioimmunoassay. Data are expressed as mean $\pm S E$. (*Indicates statistically significant differences between basal and transmural electrical stimulation under control conditions, $P \leq 0.025 .{ }^{* *}$ Indicates statistically significant difference from control basal levels, $P \leq 0.0005$. ***Indicates statistically significant difference from control transmural electrical stimulation levels, $P \leq 0.005$.)

smooth muscle is not impaired by hypoxia. Therefore, it is likely that low oxygen tensions inhibit the synthesis of NO in the corpus cavernosum.

The inhibition of cGMP accumulation under basal and electrically stimulated conditions by hypoxia provides further evidence for regulation of nitric oxide production by oxygen tension. It should be noted that low oxygen tensions were nearly as effective as L-NOARG, a potent NO synthase inhibitor, in preventing the accumulation of cGMP under basal or stimulated conditions.

A more direct demonstration of the regulatory role of oxygen is provided by the measurement of NO synthase activity in rabbit corpus cavernosum cytosol preparations. Hypoxic conditions caused a significant reduction of NO synthase activity. Thus, our findings suggest that oxygen may be a rate-limiting factor for nitric oxide production in the penile corpus cavernosum. The activity of nitric oxide synthase derived from macrophages (10) and cerebellum (19) has also been shown to be modulated by oxygen tension. In both systems, low oxygen tensions suppressed enzyme activity. NO synthase from cerebellum exhibits lower $V_{\max }$ and higher $K_{\mathrm{m}}$ values for L-arginine under hypoxic conditions (19). Recent studies have also shown that NO synthase incorporates molecular oxygen into both nitric oxide and citrulline, indicating that it is a dioxygenase (20).

Measurements performed in various organs indicate that tissue $\mathrm{PO}_{2}$ levels can be significantly lower than in venous blood (21). Furthermore, most oxygen using enzymes have a $K_{\mathrm{m}}$ that is higher than the mean oxygen concentration present in almost all tissues (21). This indicates that these oxygen-dependent enzymes may normally be faced with critical levels of oxygen substrate and makes plausible the concept of local oxygen concentrations regulating nitric oxide synthesis.

Regulation of nitric oxide-mediated trabecular smooth 

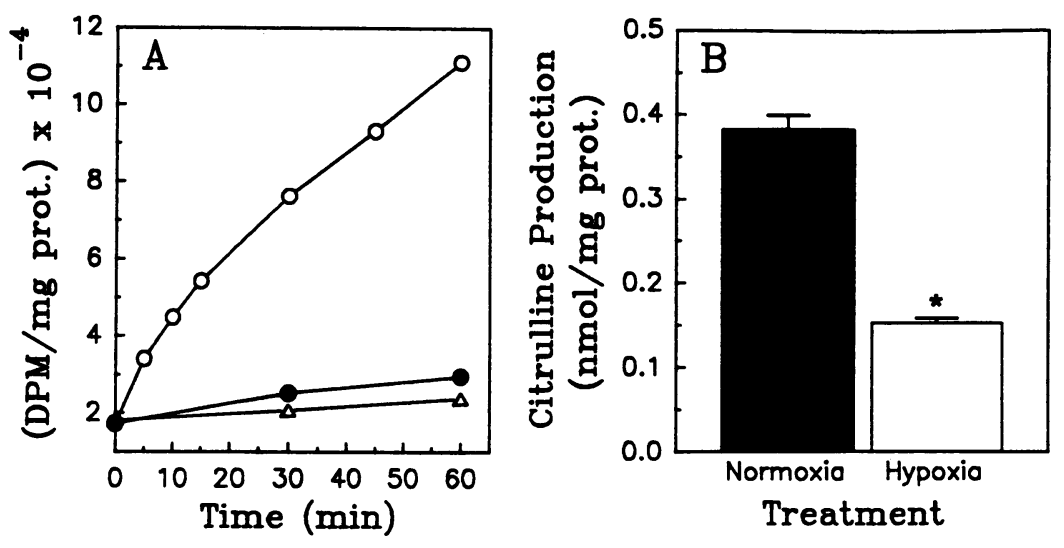

Figure 8. Rabbit cavernosal NO synthase activity. $(A)$ Time course. Rabbit corpus cavernosum cytosolic preparations were incubated at $37^{\circ} \mathrm{C}$ with $\mathrm{L}-\left[2,3-{ }^{3} \mathrm{H}\right]-$ arginine for various periods (open circles). Parallel incubations were performed at $2^{\circ} \mathrm{C}$ (solid circles) and also at $37^{\circ} \mathrm{C}$ in the presence of $3 \times 10^{-5} \mathrm{M} \mathrm{N}^{\omega}$-nitro$\mathrm{L}$-arginine (open triangles). At the indicated times, incubations were terminated by the addition of $2 \mathrm{ml}$ of ice-cold HE buffer and samples were passed through a 1-ml column of AG 50W-X8 and eluted with $2 \mathrm{ml}$ of HE buffer. The effluent was pooled and the radioactivity was quantitated using a liquid scintillation counter. Each point represents the average of duplicates. ( $B$ ) Effect of hypoxia. Rabbit cavernosal cystosol was incubated at $37^{\circ} \mathrm{C}$ with $\left[{ }^{3} \mathrm{H}\right]$ arginine under normoxic $\left(\mathrm{PO}_{2}=130-150 \mathrm{mmHg}\right)$ or hypoxic $\left(\mathrm{Po}_{2}=15-25 \mathrm{mmHg}\right)$ conditions. Parallel incuba-

tions were performed at $2{ }^{\circ} \mathrm{C}$ to determine nonspecific activity. Incubations were terminated and samples were processed as described above. $\left[{ }^{3} \mathrm{H}\right]$ citrulline production was determined by subtracting the nonspecific from the total activity. Values are expressed as mean $\pm \operatorname{SE}(n=6)$. $\left({ }^{*} \operatorname{Indicates}\right.$ statistically significant difference, $P \leq 0.0005$ ).

muscle relaxation by oxygen was observed in tissue from potent men, as well as in rabbit tissue (a healthy animal model). Thus, it appears that this may be a normal physiological mechanism regulating erection and not one that manifests itself only in impotent men. The regulation by molecular oxygen of nitric oxide synthesis, and therefore trabecular smooth muscle tone, may be of importance in the physiology and pathophysiology of the erectile function. Physiologically low oxygen tensions may participate in maintaining penile flaccidity by inhibiting nitric oxide production, while insufficient increases in oxygen tension may result in erectile dysfunction. In some instances, impaired relaxation of trabecular smooth muscle is caused by endothelial and/or nerve dysfunction, as occurs in diabetic men with impotence (22) or in hypercholesterolemic animal models (23). However, our data suggest that reduced oxygen tension can be a rate limiting factor for nitric oxide-mediated relaxation in penile corpus cavernosum regardless of the normal or pathological state of the nerves and endothelium. It is possible that men with impaired reactivity or significant obstruction of the penile arteries may not be able to increase arterial flow (and, therefore, intracavernosal oxygen tension) to sufficient levels to fully activate NO synthesis in the corpora. The inability to relax the trabecular smooth muscle would lead to impotence.

\section{Acknowledgments}

This work was supported by grants DK-39080, DK-40025, and DK40487 from the United States Public Health Service.

\section{References}

1. Saenz de Tejada, I., P. Moroukian, J. Tessier, J. J. Kim, I. Goldstein, and D. Frohrib. 1991. Trabecular smooth muscle modulates the capacitor function of the penis. Studies on a rabbit model. Am. J. Physiol. 260:H1590-H1595.

2. Krane, R. J., I. Goldstein, and I. Saenz de Tejada. 1989. Impotence. $N$. Engl. J. Med. 321:1648-1659.

3. Kim, N., K. M. Azadzoi, I. Goldstein, and I. Saenz de Tejada. 1991. A nitric oxide-like factor mediates nonadrenergic-noncholinergic neurogenic relaxation of penile corpus cavernosum smooth muscle. J. Clin. Invest. 88:112-118.

4. Ignarro, L. J., P. A. Bush, G. M. Buga, K. S. Wood, J. M. Fukuto, and J. Rajfer. 1990. Nitric oxide and cyclic GMP formation upon electrical field stimulation cause relaxation of corpus cavernosum smooth muscle. Biochem. Biophys. Res. Commun. 170:843-850.

5. Holmquist, F., H. Hedlund, and K.-E. Andersson. 1991. L- $N^{\mathrm{G}}$-nitro arginine inhibits non-adrenergic, non-cholinergic relaxation of human isolated corpus cavernosum. Acta Physiol. Scand. 141:441-442.
6. Pickard, R. S., P. H. Powell, and M. A. Zar. 1991. The effect of inhibitors of nitric oxide biosynthesis and cyclic GMP formation on nerve-evoked relaxation of human cavernosal smooth muscle. Br. J. Pharmacol. 104:755-759.

7. Rajfer, J., W. J. Aronson, P. A. Bush, F. J. Dorey, and L. J. Ignarro. 1992. Nitric oxide as a mediator of relaxation of the corpus cavernosum in response to nonadrenergic, noncholinergic neurotransmission. N. Engl. J. Med. 326:90-94.

8. Palmer, R. M. J., and S. Moncada. 1989. A novel citrulline-forming enzyme implicated in the formation of nitric oxide by vascular endothelial cells. Biochem. Biophys. Res. Commun. 158:348-352.

9. Bredt, D. S., and S. H. Snyder. 1990. Isolation of nitric oxide synthetase, a calmodulin-requiring enzyme. Proc. Natl. Acad. Sci. USA. 87:682-685.

10. Kwon, N. S., C. F. Nathan, C. Gilker, O. W. Griffith, D. E. Matthews, and D. J. Stuehr. 1990. L-citrulline production from L-arginine by macrophage nitric oxide synthase. The ureido oxygen derives from dioxygen. J. Biol. Chem. 265:13442-13445.

11. Palmer, R. M. J., A. G. Ferrige, and S. Moncada. 1987. Nitric oxide release accounts for the biological activity of endothelium-derived relaxing factor. Nature (Lond.). 327:524-526.

12. Furchgott, R. F., and J. V. Zawadski. 1980. The obligatory role of endothelial cells in the relaxation of arterial smooth muscle by acetylcholine. Nature (Lond.). 288:373-376.

13. De Mey, J. G., and P. M. Vanhoutte. 1983. Anoxia and endothelium-dependent reactivity of the canine femoral artery. $J$. Physiol. 335:65-74.

14. Lieberthal, W., E. F. Wolf, H. G. Rennke, C. R. Valeri, and N. G. Levinsky. 1989. Renal ischemia and reperfusion impair endothelium-dependent vascular relaxation. Am. J. Physiol. 256:F894-F900.

15. Johns, R. A., J. M. Linden, and M. J. Peach. 1989. Endothelium-dependent relaxation and cyclic GMP accumulation in rabbit pulmonary artery are selectively impaired by moderate hypoxia. Circ. Res. 65:1508-1515.

16. Shaul, P. W., M. A. Farrar, and T. M. Zellers. 1992. Oxygen modulates endothelium-derived relaxing factor production in fetal pulmonary arteries. $\mathrm{Am}$. J. Physiol. 262:H355-H364.

17. Lowry, O. H., N. J. Rosebrough, A. L. Farr, and R. J. Randall. 1951. Protein measurement with the Folin phenol reagent. J. Biol. Chem. 193:265275.

18. Bredt, D. S., and S. H. Snyder. 1989. Nitric oxide mediates glutamatelinked enhancement of cGMP levels in the cerebellum. Proc. Natl. Acad. Sci. USA. 86:9030-9033.

19. Rengasamy, A., and R. A. Johns. 1991. Characterization of endotheliumderived relaxing factor/nitric oxide synthase from bovine cerebellum and mechanism of modulation by high and low oxygen tensions. J. Pharmacol. Exp. Ther. 259:310-316.

20. Leone, A. M., R. M. J. Palmer, R. G. Knowles, P. L. Francis, D. S. Ashton, and S. Moncada. 1991. Constitutive and inducible nitric oxide synthases incorporate molecular oxygen into both nitric oxide and citrulline. J. Biol. Chem 266:23790-23795.

21. Vanderkooi, J. M., M. Erecinska, and I. A. Silver. 1991. Oxygen in mammalian tissue: methods of measurement and affinities of various reactions. Am. J. Physiol. 260:C1131-C1150.

22. Saenz de Tejada, I., I. Goldstein, K. Azadzoi, R. J. Krane, and R. A. Cohen. 1989. Impaired neurogenic and endothelium-mediated relaxation of penile smooth muscle from diabetic men with impotence. $N$. Engl. J. Med. 320:1025-1030.

23. Azadzoi, K. M., and I. Saenz de Tejada. 1991. Hypercholesterolemia impairs endothelium-dependent relaxation of rabbit corpus cavernosum smooth muscle. J. Urol. 146:238-240. 